\title{
ОСОБЛИВОСТІ ПРОТИДІЇ НЕЛЕГАЛЬНІЙ МІГРАЦІї В СУЧАСНІЙ УКРАЇНI
}

\author{
НОВІЧЕНКО Андрій Васильович - аспірант Харківського національного \\ університету внутрішніх справ
}

https://orcid.org/0000-0002-3569-2559

DOI 10.32782/LAW.2020.2.14

Сучасне законодавство України потребує вдосконалення у сфері нелегальноӥ мігращиї. У статті розглянуто особливості протидї нелегальній міграчиї в Украйні. Особлива увага звертається на загрози, які можуть виникати зі збільшенням ї̈ випадків, та відповідну діяльність Державної міграиійної служби України. Розкрито основний зміст міжнародних нормативно-правових актів, спрямованих на координащію дій у сфері протидї нелегальній мігращиї. 3'ясовано, що кількість украӥниів-емігрантів поступово збільшується і за останні роки стала, такою, що загрожує начіональній безпещі України. Визначено, шо Украӥна перетворюеться в країну тривалого перебування нелегальних мігрантів. Зазначено, що бормування начіональної системи законодавства протидї нелегальній (незаконній) міграцй-це досить складний процес взаємозв'язку з міжнародно-правовими стандартами у сбері протидії нелегальній міграчї, боротьби з організованою злочинністю та захисту основних прав нелегальних мігрантів та біжениів. Тому нелегальна міграція в Україні є дуже гострою проблемою, що впливає на стан правопорядку в суспільстві, економічну ситуацію, яка ставить під сумнів авторитет нашої держави на міжнародній арені.

Ключові слова: міграчія, імміграчія, еміграиія, Державна міграиійна служба, Міністерство внутрішніх справ

Постановка проблеми

Проблематикою забезпечення правового порядку та безпеки в України $є$ створення ефективних на законодавчому рівні способів протидії нелегальній міграції, які 6 сприяли запровадженню дієвих заходів з боротьби зі злочинністю, пов'язаною 3 нелегальною міграцією.

Аналіз останніх досліджень

Вивченням цього питання займались такі українські вчені: Ю. Бузицький, А. Бабенко, С. Бритченко, О. Войцехівський, В.Коваленко, В.Кривенко, О.Кузьменко, В.Куц, О.Джужа, Ю. Кравченко, О. Малиновська, О. Надьон, А. Черняк, С. Чехович, О. Піскун, І. Прибиткова, Ю. Римаренко, В. Трощинський, В. Шакун, та ін., так і зарубіжні вчені Дж. Солт, М. Війєрс, Р. Хавсман, Р. Вольвенд, В. Аунєєв, П. Холмс, М. Пуглі, А. Шлоенхард та ін. Однак, незважаючи на загальний підвищений інтерес до протидії нелегальній міграції, особливості протидії нелегальній міграції є досить важливими для розроблення правового механізму протидії такому явищу, як нелегальна міграція.

\section{Мета статті}

Виділити та проаналізувати особливості протидії нелегальній (незаконній) міграції в Україні.

\section{ВикАад основного матеріалу}

Нелегальна міграція є складовою терміну «міграція», що походить від латинського «migro, migrate»: переселення, переміщення.

Міграція внутрішня - переселення, просторове пересування, переміщення мешкан- 


\section{Кримінальне право, кримінальний процес та криміналістика}

ців країни, пов'язане зі зміною місця проживання в межах цієї країни. Найпомітнішою ознакою внутрішніх міграцій населення України після 1991 було зменшення їх інтенсивності (наприкінці 1980-х рр. мігрували 3-3,5 млн. осіб щорічно, нині - 1,6 млн.), що викликано економічними негараздами, труднощами 3 працевлаштуванням, обмеженням доступу до навчання на виїзді через його високу вартість тощо. Більше половини внутрішніх переїздів здійснюється всередині регіонів і до третини - між ними. Найпотужнішими є міграційні потоки між сусідніми областями. Основним реципієнтом у міжрегіональному обміні населенням є місто Київ.

Міграція зовнішня (міждержавна) - переміщення з однієї держави на територію іншої для постійного або тимчасового проживання. Кількість мігрантів, тобто осіб, які проживають не в тих країнах, де вони народилися, 1910 становила 33 млн. в усьому світі. Через 55 років вона подвоїлася (65 млн. у 1965). Однак у 1990 у світі було вже 120 млн., а на початку 21 ст. -175 млн. мігрантів. Міграція поділяється на еміграцію, тобто вибуття, та імміграцію, або прибуття. Найбільше відповідає змістові поняття «міграція» незворотна, тобто остаточне переселення. Усі інші їі види можна назвати тимчасовими. Одним з найбільш поширених 3 них є трудова міграція (міграція робочої сили) - переміщення з метою працевлаштування. У світі налічується щонайменше 70 млн. працівників-мігрантів. Широкого поширення набули вимушені міграції. Зумовлені політичними, етнічними та іншими переслідуваннями, воєнними конфліктами, потоки біженців обчислюються приблизно 20 млн. осіб. Зовнішні міграції населення в сучасній Україні зазнали істотних змін. Їх розвиток відбувався, з одного боку, під впливом традиційних міграційних зв'язків, а 3 іншого - у рамках цілком нових географічних, правових та економічних реалій, створених виникненням нових держав, ринковими реформами, більшою відкритістю до світу, включенням у світові міграційні процеси [1].

За підрахунками Служби безпеки України, через територію України проходить щороку близько 50 тисяч нелегалів. Аналітики СБУ називають шість постійних міжнародних каналів незаконного переправлення нелегалів, які функціонують уже не перший рік:
1. Індо-пакистанський. Проходить за маршрутом: Індія (Пакистан) - Іран - Закавказький регіон - Росія - Україна - Західна Европа. Або через середньоазійські республіки колишнього СРСР і далі за цим же напрямком.

2. Шрі-ланкійсько-бангладеський. Маршрути: Шрі-Аанка - Об'єднані Арабські Емірати - Болгарія - Росія - Україна - Західна Европа; Шрі-Ланка - Казахстан (Узбекистан) Росія - Україна - Західна Европа; Шрі-Ланка - Індія - Україна - Західна Европа.

3. Афганський. Маршрути: Афганістан - Пакистан - Іран - Азербайджан - Росія Україна - Західна Европа; Афганістан - середньоазійські республіки колишнього СРСР - Росія - Україна - Західна Европа.

4. Китайський. Переміщення громадян Китаю здійснюється переважно за маршрутом: Пекін - Москва - Київ - Аьвів - Пшемисль - Краків - країни Західної Европи.

5. В'єтнамський. Громадяни В'єтнаму, які раніше працювали на території СРСР за контрактами, а тепер не бажають повертатися на батьківщину, а також ті, що прибувають до країн СНД туристичними каналами, використовують підроблені закордонні службові паспорти, виготовлені, як правило, у Москві.

6. Арабсько-курдський. Громадяни Ірану, Іраку, Сирії, Йорданії, Сгипту, Лівану, Палестини прибувають до України, як правило, за дійсними національними паспортами повітряним і морським шляхом з метою подальшої нелегальної міграції на Захід [2].

Державна міграційна служба України створена Указом Президента України «Про оптимізацію системи центральних органів виконавчої влади» від 09.12.2010 № 1085/2010. У квітні 2011 року Указом Президента України від 06.04.2011 № 405/2011 затверджено Положення про Державну міграційну службу України, яким визначено основні завдання, функції та повноваження ДМС України. У серпні 2014 року Постановою Кабінету Міністрів України №360 від 20.08.2014 затверджено нове Положення про Державну міграційну службу України.

Державна міграційна служба України (ДМС) є центральним органом виконавчої влади, діяльність якого спрямовується та координується Кабінетом Міністрів України через Міністра внутрішніх справ і який ре- 
алізує державну політику у сферах міграції (імміграції та еміграції), у тому числі протидії нелегальній (незаконній) міграції, громадянства, реєстрації фізичних осіб, біженців та інших визначених законодавством категорій мігрантів. ДМС у своїй діяльності керується Конституцією та законами України, указами Президента України та постановами Верховної Ради України, прийнятими відповідно до Конституції та законів України, актами Кабінету Міністрів України, іншими актами законодавства.

Основними завданнями ДМС є:

- реалізація державної політики у сферах міграції (імміграції та еміграції), у тому числі протидії нелегальній (незаконній) міграції, громадянства, реєстрації фізичних осіб, біженців та інших визначених законодавством категорій мігрантів;

- внесення на розгляд Міністра внутрішніх справ пропозицій щодо забезпечення формування державної політики у сферах міграції (імміграції та еміграції), у тому числі протидії нелегальній (незаконній) міграції, громадянства, реєстрації фізичних осіб, біженців та інших визначених законодавством категорій мігрантів.

ДМС України відповідно до покладених на неї завдань (основні функції ДМС України):

- проводить аналіз міграційної ситуації в Україні, проблем біженців та інших категорій мігрантів, розробляє поточні та довгострокові прогнози із зазначених питань;

- готує пропозиції щодо визначення квоти імміграції на календарний рік;

- ухвалює рішення про видачу дозволу на імміграцію, відмову в його видачі та скасування такого дозволу;

- бере участь у межах, визначених законодавством, у вирішенні питань трудової міграції та питань, пов'язаних із навчанням в Україні іноземців та осіб без громадянства;

- ухвалює рішення про продовження (скорочення) строку тимчасового перебування іноземців та осіб без громадянства на території України, про добровільне повернення або примусове повернення іноземців та осіб без громадянства до країн їх громадянської належності або країн походження, звертається до судів 3 позовами про примусове видворення іноземців та осіб без громадянства, здійснює заходи, пов'язані з примусовим видворенням іноземців та осіб без громадянства з України;

- здійснює ідентифікацію громадян України, які втратили документи, що посвідчують особу, та осіб, які звернулися із заявами про визнання біженцем або особою, яка потребує додаткового захисту в Україні, а також іноземців та осіб без громадянства, які втратили документи, що посвідчують особу, та підлягають видворенню або реадмісії;

- виконує функції замовника 3 виготовлення та постачання бланків паспортних та інших документів, що посвідчують особу;

- здійснює розроблення зразків заяв про визнання біженцем або особою, яка потребує додаткового захисту, та довідки про звернення за захистом в Україні;

- ухвалює рішення про визнання іноземців та осіб без громадянства біженцями або особами, які потребують додаткового захисту, про втрату, позбавлення статусу біженця або додаткового захисту і про скасування рішення про визнання біженцем або особою, яка потребує додаткового захисту;

- збирає та аналізує інформацію про наявність у країнах походження біженців та осіб, які потребують додаткового та тимчасового захисту в Україні, умов, за яких такий захист надається;

- надсилає компетентним органам влади інших держав запити щодо наявності в таких державах членів сім'ї осіб, які подали заяви про визнання біженцями або особами, які потребують додаткового захисту, чи яких було визнано біженцями або особами, які потребують додаткового захисту, і правових підстав для возз'єднання сімей;

- розглядає скарги на рішення про відмову у прийнятті заяви про визнання біженцем або особою, яка потребує додаткового захисту, про відмову в оформленні документів для вирішення питання щодо визнання біженцем або особою, яка потребує додаткового захисту, і скасування зазначених рішень, якщо вони були прийняті з порушенням законодавства;

- вживає у межах компетенції заходів для сприяння реалізації прав біженців та інших категорій мігрантів;

- здійснює оформлення і видачу посвідчення біженця, посвідчення особи, якій на- 


\section{Кримінальне право, кримінальний процес та криміналістика}

дано додатковий захист в Україні, а також інших документів, передбачених законодавством для цих категорій осіб;

- видає проїзні документи іноземцям та особам без громадянства, яких було визнано біженцями іншими країнами - учасниками Конвенції про статус біженців 1951 року та/ або Протоколу щодо статусу біженців 1967 року;

- забезпечує функціонування пунктів тимчасового розміщення біженців та пунктів тимчасового перебування іноземців та осіб без громадянства, які незаконно перебувають в Україні;

- бере участь у реалізації державної політики у сфері волонтерської діяльності щодо надання допомоги біженцям;

- подає МВС для подальшого внесення Кабінетові Міністрів України пропозиції щодо необхідності прийняття рішення про тимчасовий захист (припинення тимчасового захисту), веде реєстрацію осіб, яким надано такий захист;

- здійснює реєстрацію (зняття з реєстрації) місця проживання (перебування) фізичних осіб, веде відповідний реєстраційний облік;

- веде облік осіб, які отримали або які претендували на отримання статусу біженця чи особи, яка потребує додаткового захисту, осіб, які набули (припинили) громадянство України, та осіб, яким надано (скасовано) дозвіл на імміграцію в Україну, на всіх етапах проведення відповідних процедур;

- забезпечує створення, удосконалення, розвиток, супроводження та підтримку функціонування Єдиного державного демографічного реєстру, Національної системи біометричної верифікації та ідентифікації громадян України, іноземців та осіб без громадянства, розпорядником яких 6 ДМС, а також здійснюе заходи із захисту інформації в них;

- забезпечує підтримку функціонування Державної інформаційної системи реєстраційного обліку фізичних осіб та їх документування для створення Сдиного державного демографічного реєстру;

- забезпечує у межах повноважень, передбачених законом, формування інформаційних ресурсів (баз, банків даних) щодо персональних даних фізичних осіб (у тому числі їх біометричних даних, параметрів), інших інфор- маційних ресурсів, необхідних для виконання покладених на ДМС завдань;

- здійснює відповідно до закону заходи щодо запобігання та протидії нелегальній (незаконній) міграції, іншим порушенням міграційного законодавства;

- здійснюе міжнародне співробітництво, бере участь у розробленні проєктів та укладенні міжнародних договорів України 3 питань громадянства, міграції, біженців, осіб, які потребують інших форм захисту, реєстрації фізичних осіб та реадмісії, забезпечує в межах своїх повноважень виконання укладених міжнародних договорів України;

- здійснюе відповідно до закону державний контроль за дотриманням законодавства у сферах міграції (імміграції та еміграції), у тому числі протидії нелегальній (незаконній) міграції, громадянства, реєстрації фізичних осіб, біженців та інших визначених законодавством категорій мігрантів у передбачених законодавством випадках, притягає порушників до адміністративної відповідальності. [3], [4]

Якщо до 2014 року основними причинами виїзду громадян України можна було назвати три, а саме: туризм, відпочинок, бізнес та виїзд на постійне місце проживання, то зараз вектор кардинально змінюється. Аюди вимушено покидають місце проживання загалом, по-перше, через нестабільність і військові дії; по-друге, в пошуках роботи; по-третє, з метою налагодження власного бізнесу або участі в бізнесових структурах. [5]

Згідно з показниками діяльності Державної міграційної служби України за I півріччя 2017 року:

- на порушників міграційного законодавства накладено штрафів у розмірі 1568413 гривень;

- виявлено нелегальних мігрантів: 3330 осіб (з них 2355 чоловіків, 975 жінок);

- ухвалено рішень по затриманим нелегальним мігрантам: 3929 (про добровільне повернення: 11 осіб; про примусове повернення: 3198 осіб; про примусове видворення: 122 осіб; про заборону в’їзду в Україну: 487 осіб; поміщено до пунктів тимчасового перебування іноземців: 111 осіб; виконано рішень про примусове повернення: 1047 осіб; видворено нелегальних мігрантів у примусовому порядку: 53 особи). [6] 


\section{Висновки}

Безумовно, вказані показники свідчать про дієвість роботи Державної міграційної служби та, виходячи з цього, змін у законодавстві України з оптимізації центральних органів виконавчої влади. Питання протидії нелегальній міграції стояло впродовж багатьох років української незалежності, ця проблематика опрацьовувалася вченими та науковцями. Але подальші результати та, власне, їх практичне значення покаже час. Необхідно зазначити, що особливості такого процесу, як нелегальна міграція, є стихійність, масовість, неконтрольованість такого процесу, який може дестабілізувати внутрішню ситуацію в країні. Основною особливістю протидії такому процесу $є$ розроблення комплексної програми адміністративно-правової протидії нелегальній міграції.

\section{Аiтература}

1. Енциклопедія історії України: Т. 6: ЛаМi / Редкол.: В. А. Смолій (голова) та ін. НАН України. Інститут історії України. - К.: В-во «Наукова думка», 2009. - 790 с.: іл. - Режим електронного доступу: http://resource.history. org.ua/cgi-bin/eiu/history.exe?Z21ID=\&I21DBN $=\mathrm{ELIB} \& \mathrm{P} 21 \mathrm{DBN}=\mathrm{ELIB} \& \mathrm{~S} 21 \mathrm{STN}=1 \& \mathrm{~S} 21 \mathrm{RE}$ $\mathrm{F}=10 \& \mathrm{~S} 21 \mathrm{FMT}=$ elib all\&C $21 \mathrm{COM}=\mathrm{S} \& \mathrm{~S} 21 \mathrm{CN}$ $\mathrm{R}=20 \& S 21 \mathrm{P} 01=0 \& \mathrm{~S} 21 \mathrm{P} 02=0 \& \mathrm{~S} 21 \mathrm{P} 03=\mathrm{ID}=\&$ $\underline{\text { S21COLORTERMS }=0 \& \text { S21STR }=0002222}$

2. Ірина Кресіна, Олена Стойко: «Нелегальна міграція: проблеми протидії та правового регулювання». Інститут політичних i етнонаціональних досліджень ім. І.Ф. Кураса НАН України. Режим електронного доступу: http://www.ipiend.gov.ua/uploads/pm/pm_36/ krasina_nelehalna.pdf

3. 3. Сайт Державної міграційної служби України. Історична довідка. Режим електронного доступу: $4 . \quad$ https://dmsu.gov.ua/prodms/zagalna-informacziya.html

5. Постанова Кабінету Міністрів України від 20 серпня 2014 р. № 360. Положення про Державну міграційну службу України. Ре-
Modern Ukrainian legislation needs to be improved in the area of irregular migration. The article considers the specifics of combating irregular migration in Ukraine. Particular attention is paid to the threats that may arise with an increase in cases of irregular migration, and the relevant activities of the State Migration Service of Ukraine.

The main content of international legal acts aimed at coordinating actions in the field of combating irregular migration is discussed. It was found that the number of Ukrainian emigrants is gradually increasing and in recent years has become a threat to Ukraine's national security. It is determined that Ukraine is becoming a country of long-term stay for irregular migrants. It is noted that the formation of a national system of legislation to combat irregular migration is a complex process of interrelation with international legal standards in the field of combating irregular migration, combating organized crime and protecting the fundamental rights of irregular migrants and refugees.

Therefore, irregular migration in Ukraine is a very acute problem that affects the state of law and order in society, the economic situation, which calls into question the authority of the state in the international arena.

Keywords: migration, immigration, emigration, State Migration Service, Ministry of Internal Affairs

жим електронного доступу: http://zakon5.rada. gov.ua/laws/show/360-2014-\%D0\%BF

6. Денисова Т.А., «Міграційні процеси в Україні: сучасний стан і проблеми незаконної міграції», «Держава та регіони», серія: «Право» 2016, № 2 (52), ст. 72-76. Режим електронного доступу: http://www.law.stateandregions. zp.ua/archive/2_2016/16.pdf

7. Показники діяльності ДМС заI півріччя 2017 року, офіційний сайт Державної міграційної служби України, режим електронного доступу: https://dmsu.gov.ua/assets/ files/statistic/year/2017_6.pdf 